\title{
Péter Forgács: imágenes de familia y la memoria del Holocausto
}

\section{Martins, Claudia}

Resumen:

Este artículo se propone una lectura del largometraje Bartos Family (1982), del cineasta húngaro Peter Forgács. El análisis se va a enfocar en el uso de materiales de archivos familiares.

Forgás utiliza archivos de una misma familia húngara entre las décadas de 1920 y 1950 , y mientras nos muestra el cotidiano de este grupo, también nos presenta hechos históricos previos y posteriores a la ascensión del nazismo. El director manipula las imágenes pero no las saca del contexto original: la sociedad húngara de la época. El encuentro entre espectador actual con esas imágenes del pasado es lo que produce una nueva manera de mirar hacia la

Cuadernos del Centro de Estudios de Diseño y Comunicación Nº 62

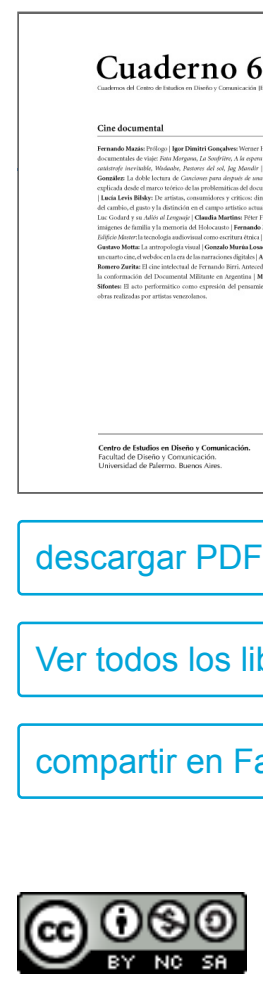

Esta obra está bajo una Licencia Creative Commons Atribución-NoComercialCompartirlgual 4.0 Internacional historia. El estudio pretende analizar las técnicas de montaje utilizadas por el director y de qué manera se produce el impacto del found footage en el espectador del presente.

Palabras clave: found footage - archivo familiar - nazismo - montaje.

(*) Licenciada en Comunicación Social en la Universidad Católica de Río de Janeiro, Brasil (PUC-RJ). Alumna de la Maestría en Cine Documental de la Universidad del Cine. Orienta su investigación de tesis a la utilización del found footage, en particular, archivos familiares, en documentales brasileños contemporáneos. El cineasta húngaro Péter Forgács empezó a coleccionar imágenes de archivo familiares en 1982, a través de anuncios que publicaba en los periódicos de la época. Durante años logro reunir un material compuesto por imágenes familiares de las décadas de 1920 hasta 1950.

Esas imágenes caseras eran de familias europeas, principalmente húngaras, que hacían parte de la burguesía del periodo anterior al Holocausto, durante la ascensión del nazismo. 
Forgács trabaja con la memoria del horror de una manera distinta, pues elige momentos de aparente felicidad de las familias burguesas. Además del estilo de montaje e intervención del realizador, esas imágenes buscan transmitir el impacto del horror justamente por la memoria del espectador en relación al pasado; es decir, nosotros ya sabemos lo que fue el Holocausto. Entonces, el encuentro entre dos memorias: las imágenes hogareñas que son un recorte de la sociedad de la época, y la memoria histórica de cada espectador trabajan juntas para transmitir el mundo histórico documental. El realizador utiliza técnicas de edición como la voz off, los carteles en las imágenes, las imágenes congeladas, cambia el ritmo de las tomas y también incluye coloraciones en las imágenes. "La estética contemporánea de found footage puede reconocerse en esa invención soviética que lleva el constructivismo pictórico al cine, porque ambas conciben las imágenes, y el vínculo de estas con la realidad referida, de modo materialista y porque en ambas el montaje es el procedimiento soberano"1. De esta manera es imprescindible ubicar Forgács en el lugar de realizador contemporáneo de documentales de found footage.

El impacto de las imágenes de archivo familiar se da justamente por el tipo de montaje propuesto por Forgács. Con una narración intima, utilizando su propia voz, presenta la vida de las familias y de los personajes de la historia real. La narración, la música, y la manera como conduce las historias es lo que posibilita la identificación del espectador, mas específicamente: una identificación afectiva del espectador con los personajes. Es esa afección que permite la comprensión del horror del Holocausto, aunque el director nunca nos muestre tales imágenes. Forgács no busca presentar una verdad absoluta en sus películas, tampoco exponer de manera explicativa y didáctica lo que sucedió, sino que involucrar el espectador lo máximo posible; trabajar con el inconsciente de los espectadores.

En ese articulo pretendo trabajar con la película Bartos Family, de Péter Forgácas. En la película propongo analizar el uso que el director hace de materiales de archivo familiar y también identificar su manera particular de transmitir el horror del Holocausto.

\section{Bartos Family}

La película Bartos Family es de 1988 y es la primera de la serie Private Hungary que se dedica a contar la historia de la burguesía de Hungría a partir de imágenes de archivos de familias húngaras. Forgács utiliza las imágenes privadas como documento para retratar la sociedad de la época, y es ese tipo de utilización que legitima la película.

Forgács presenta elementos que nos cuenta la relación de la familia Bartos y nos ubica en el tiempo y el local con los carteles presentados al comienzo de la película. El primer plano donde nos presenta la familia están todos en un plano abierto, mientras tanto, la voz en off de Forgács presenta cada personaje de la familia, comenzando por el jefe de la familia. El último personaje a ser presentado es Zoltán Bartos, el hermano mayor y el camarógrafo; es él el personaje más importante, porque durante toda la película es su punto de vista que vamos a observar. Lo más interesante del material de Zoltán es que sus grabaciones no son solamente amateur y familiares, pues podemos ver que muchas escenas son armadas, como si existiera un guión previo. Las imágenes de Zoltán nos muestran su preocupación con el encuadre, con la historia presentada y también con el montaje interno del plano. 
Forgács invita al espectador a conocer la vida de esta familia burguesa de Budapest cuando dice: "ahora vamos a conocer la familia Bartos", como si nos invitara a cumplir con el rol de voyeur; y al mismo tiempo comenta que vamos a ser testigos de un tiempo y una historia al decir que el relato acompaña la muerte de Stalin hasta de la segunda guerra mundial. De esta manera, el director transita entre dos historias: la privada y la publica; y es justamente la mezcla de las dos que le da fuerza al relato. La familia burguesa es presentada siempre de manera jerárquica, empezando con el papa ("el jefe de la familia"), seguido por los tres hermanos, mientras que las mujeres se quedan en un segundo plano y son presentadas siempre en relación a un hombre, es decir, son presentadas como esposas y mamás. Esa presentación transmite el peso y la importancia dedicada al status de las personas en la sociedad burguesa de la época. Al hijo menor, Otto, Forgács le dedica bastante tiempo y nos muestra toda su vida, desde bebe hasta adulto, es como si el espectador pudiera acompañar la construcción de un burgués. Durante todo el comienzo de la película es clara la relación de los personajes con la plata y el tipo de trabajo que los hombres ejercían, como empresarios exitosos. La importancia que Forgács le da al trabajo y a industria es muy notada el la banda sonora, pues cuando nos presenta la familia escuchamos nada más que una música, mientras cuando las imágenes nos muestran un ambiente industrial empezamos a escuchar el sonido ambiente característico de la fábrica.

Esa intervención del sonido ambiente sigue en casi todos los planos que muestran la fábrica.

Todo el comienzo de la película nos presenta nada más que la historia particular de esta familia burguesa sin hacer ningún comentario pertinente sobre los eventos históricos de la época. De esta manera, nos llama la atención esa indiferencia, y capaz esto se de porque justamente a la familia Bartos no le importaba mucho los eventos externos del país y del mundo, sino que sus vidas particulares en la sociedad burguesa de Budapest.

Muchas veces el tiempo de la película no es lineal y salta algunos años para después volver al tiempo lineal. Un ejemplo es cuando vemos Amin casarse con su segunda esposa, en 1931, para después volver a 1922 y la historia de Otto, el hijo menor. El tiempo de la película muchas veces es circular y se fija en cada personaje de la familia y su vida, para después volver al grupo. Ese tiempo presentado en el montaje de Forgács nos remite de una cierta manera a las historias orales que son contadas en círculos familiares, donde no hay preocupación exacta con la linealidad, sino con las anécdotas de cada miembro de la familia.

A pesar de las imágenes hechas por Zoltán no explicitaren el momento histórico de Hungría en la época, Forgács con su narración añade pequeños y simples comentarios que nos llevan a comprender la relación de los personajes con la historia política del momento. Un ejemplo de eso es un comentario hecho por Forgács donde explicita que la segunda esposa de Amin le pide que le cambie el nombre por uno que suene más cristiano, como Andor.

Ese pequeño y simple comentario nos lleva a comprender que parte de la sociedad de la época estaba conforme con la ascensión del fascismo o no comprendía lo que era y lo que representaba el fascismo.

Las imágenes hechas por Zoltán Bartos nos muestran que la burguesía húngara no se dio cuenta de la llegada del Nazismo, eso vemos en el viaje por Europa, cuando Zoltán se va a Austria, Alemania, Francia y Holanda. Las imágenes de Zoltán no nos muestra absolutamente nada de diferente, pero el simples comentario de Forgács ya provoca la reacción en el espectador frente a la contracción de la memoria colectiva y la memoria individual de Zoltán Bartos. En ese sentido, la memoria colectiva de la historia y la memoria privada de la familia 
Bartos se chocan de manera muy fuerte y provocan la sensación de espectador omnisciente. Consuelo Lins2 comenta que la mezcla entre lo que nosotros sabemos de la historia y lo que todavía no saben los personajes es lo que hay de más asustador en las películas de Forgács, por eso, la autora afirma que son muchas las veces que el espectador tiene la reacción de decirles a los personajes: huyan! La utilización de estas imágenes es una actitud artística y política que hace diluir el objetivo inicial de este material -los films de familia hechos para que la familia los vea, con el objetivo de fortalecer los lazos y el grupo- ahora es utilizado para darle un nuevo sentido. Las imágenes ya no tienen más el objetivo de perpetuar la historia familiar, sino que estas imágenes se vuelven testigos de la historia mundial, son compartidas y producen experiencias inéditas a un publico desconocido3. Los primeros planos históricos en las imágenes de Zoltán son de dos hombres haciendo el saludo fascista durante las vacaciones de Zoltán. Luego después de estas imágenes seguimos viendo a Zoltán disfrutar de sus vacaciones, sin darse cuenta de los cambios históricos.

Después que regresan de las vacaciones vemos la imagen de Miska Grósz, amigo de Zoltán, con un comentario que dice: "desaparecido en la frente rusa, en 1944, trabajador forzado judío". En ese momento las imágenes de la película se vuelven un poco más políticas, como si ahora el interés de Zoltán fuera más ubicarse como testigo de la historia que hacer grabaciones de su familia. En el montaje, Forgács empieza a marcar en sus comentarios las fechas históricas y los sucesos en Budapest, como por ejemplo: "La mano del trafico en Budapest ha cambiado en 1940 de acuerdo con ordenes alemanes". Entonces, empieza a narrar la guerra entre Hungría y Unión Soviética.

Zoltán empieza a filmar carteles de guerra y eventos políticos, como la feria internacional de armas en Hungría, y un desfile militar. El montaje acelera el ritmo y cambia la música.

Así como las imágenes de Zoltán cambian, el montaje de Forgács también, y el director empieza a añadir comentarios más específicos con datos de la guerra, como cuando narra el bombardeo en Budapest y las consecuencias para la sociedad: "Los alemanes bombardearon todos los puentes. Sesenta por ciento de las casas fueron destruidas, mataron a seiscientos mil húngaros judíos, y el segundo ejercito húngaro fue destruido". Al sonido ambiente el director le agrega ruidos de guerra y de marchas militares de una manera siempre creciente. La realidad de la historia del país destruye el sueño burgués presentado anteriormente.

Los personajes de la familia Bartos son inseridos en el caos de la guerra cuando Forgács nos cuenta los que sobrevivieron y los que no resistieron al horror. La única muerte que habíamos visto hasta el momento era de la primera mujer de Amin Bartos, siempre asociada al sonido de la cámara, como si la cámara fuera capaz de mantener su memoria.

Ya al final de la película este mismo sonido de la cámara es puesto con la secuencia de Budapest destrozada por los bombardeos, como si el realizador nos quisiera decir que hasta ese momento la muerte era nada más que un tema familiar y particular, pero ahora la muerte se vuelve pública y amenaza diariamente los que viven allí. La historia burguesa que al comienzo tenía el carácter de privacidad se pierde con la guerra, y esa historia se vuelve pública.

Lo que hace Forgács en la película es poner en evidencia las relaciones familiares y poner en evidencia los sucesos históricos antes y después de la segunda guerra. En Bartos Family las imágenes de archivo no están 
puestas como documentos informativos sobre la historia de Hungría, pues como se puede ver en la película no hay nada históricamente novedoso.

La búsqueda de Forgács es trabajar la esencia emocional de estas imágenes y desde ahí involucrar el espectador. Las imágenes familiares no son utilizadas con inocencia por parte de Forgács, él tiene muy claro que este tipo de imagen produce una identificación afectiva, y una nostalgia en el espectador. De esta manera, el director utiliza la afectividad para provocar una reflexividad en su espectador. Sus comentarios a lo largo de la película dejan claro que él tiene la intención de hacer con que el espectador crie sus propias preguntas y respuestas. No hay un discurso militante en su película, y tampoco Forgács tiene la intención de transmitir un mensaje predeterminado, y deja la interpretación a cargo de los espectadores.

\section{El found footage propuesto por Péter Forgács y la memoria del Holocausto}

De acuerdo con Antonio Weinrichter lo que guía la actitud del compilador de imágenes privadas "no es tanto la denuncia o el afán de explorar la inscripción de trazas ideológicas como la recuperación de una memoria desvanecida; y la interrogación que se hace de las imágenes apropiadas es menos política que poética"4. De esta manera, al mirar Bartos Family es posible ubicar Péter Forgács en esta clase de compiladores, pues la utilización que hace de las imágenes es más poética que política, a pesar de haber algunos comentarios políticos que describen la época de la segunda guerra, él se concentra en narrar la historia de esta familia. En el mismo texto, Weinrichter reconoce a Forgács como siendo una de las mayores figuras de este tipo de compilación moderna presentando las historias de húngaros desconocidos.

Forgács utiliza el metraje encontrado de la familia Bartos de una manera deconstructiva, pues a la vez que la niega; como cuando hace sus comentarios sobre la guerra contrapuestos con las imágenes de la familia; también la afirma haciendo emerger los sentidos que ellas no tenían la intención de mostrar, como la indiferencia de la clase burguesa en relación a los acontecimientos históricos. Sin embargo, el director no neutraliza en ningún momento los sentidos originales de estas imágenes, las mantiene como imágenes de familia. Lo contemporáneo del found footage está, pues, no sólo en el saber de la discrepancia estatutaria entre imagen y realidad sino en el saber de que los sentidos de las imágenes son siempre ya inestable, ambivalentes y que estos dependen de las combinaciones virtualmente inagotables en que se las haga participar5. A pesar de mantener el sentido original de las imágenes encontradas, Forgács las remonta y utiliza recursos de montaje cambiándoles y dándoles otra forma. Los principales ejemplos de eso son los freeze frames, los subtítulos, y $\sin$ embargo, la voz que guía el espectador. En esto, el found footage de la contemporaneidad es una estética de cierta preservación, porque protege al reproducir, aun refilmándolo y remontándolo, el material original, ya a la vez de deconstrucción, porque en la misma preservación transforma. Se trataría una suerte de restauración que incide sin embargo en el original para afectarlo, una restauración que no conserva6. A diferencia de Histoire(s) du cinema, de Godard, Forgács conoce el estatuto de las imágenes ajenas y quien las filmó, por otro lado, el trabajo que hace es semejante a lo que hace el director francés, porque también tiene la finalidad de contar la historia política y la ascensión del nazismo aunque no utilice imágenes de guerra. No obstante, el realizador húngaro también trabaja con las capas temporales, no en la imagen como tal, sino utiliza su narración y la memoria colectiva de los espectadores para hacerlo.

Al contrario de lo que hace Ken Jacobs, en su película Tom, Tom, The Piper's Son, Forgács no manipula las imágenes al punto de desintegrarlas, pues las remonta buscando afectar el espectador no de manera sensorial, 
sino que se dirige a la memoria y al saber de quien ve la película. De esta manera, a pesar de las intervenciones que hace en las imágenes, Bartos Family jamás puede ser reconocida como una película experimental, pues posee todas las características del cine documental de found footage. Lo documental reside en otro uso de la imagen encontrada, por el cual no se recurre a ese proceso de horodación, propio del cine experimental, sino más bien, podría decirse, a una excavación. La diferencia entre uno y otro tratamiento es que el primero es de una negatividad que la búsqueda de los sentidos posibles de la imagen limita en el documental. El documental de found footage trabaja con el metraje encontrado para, analizando sus capas, hacer visible aquello que no ha sido visto, mostrar en los nuevos encadenamientos sentidos que entran en conflicto con aquellos originalmente asignados o que permanecían ocultos7. En Bartos Family se puede ver la preocupación del director en poner en evidencia la indiferencia de la sociedad en relación a los acontecimientos políticos, lo que va en contra el sentido original de las imágenes familiares hechas por Zoltán. En ese sentido, Forgács indaga a las imágenes, las excava y revela la posición de la burguesía húngara frente a la ascensión del nazismo. Sin embargo, en ningún momento el director explicita esa reflexión, y tal conclusión es trabajo del espectador que ya conoce la historia del pasado y es invitado a revisitar la cotidianeidad de estos personajes que están muertos, pero que por el carácter de las imágenes privadas provocan una identificación afectiva con quien las mira.

Una de las características más importantes de esta obra de Forgács es la utilización de imágenes familiares, y es justamente eso que provoca la reacción y la identificación del espectador con el mundo histórico presentado por el director. El cine de material casero encontrado exhibe una cualidad reflexiva más misteriosa e inefable: el hecho de que sean imágenes reales privadas, no puestas en escena, acentúa la tenebrosa relación del cine con el tiempo, esa capacidad de embalsamiento de que hablara Bazin8. Lo que le da la fuerza son los personajes reales de familia Bartos, la manera como se mueven en la pantalla como si estuvieron todos vivos en el momento mismo de la proyección.

Aunque no veamos escenas literales de la guerra misma, pasamos toda la primera parte de la película imaginando lo que pasara con la familia durante la ascensión del nazismo. Otro punto importante de la película es el sonido utilizado por Forgács que le da la carga narrativa necesaria para el relato histórico, y sobre todo le pone ritmo. El realizador no deja que la película hable por si sola, sino que añade algunos comentarios, y la música muchas veces funciona como uno de esos comentarios. "La atmósfera que imprime al material de Forgács la música de Szemzo -que ancla la dirección del documental biográfico de una saga familiar, si bien no logra agotar del todo el misterio de las imágenes"9. En ese sentido, Weinrichter opina que el realizador no utiliza la música de manera obvia, y por su vez, el sonido no quita la fuerza que esta en las imágenes montadas por el director húngaro.

\section{Conclusión}

La utilización de imágenes de archivo también puede ser vista en la película Noche y Niebla, de Alain Resnais, pero en este caso, las imágenes son hechas por norte-americanos desconocidos, es decir, no se sabe quien las hizo. Esa es una de las grandes diferencias entre Bartos Family, pues la película de Forgács trabaja con una mirada especifica: la del burgués que graba su familia, es justamente esa mirada que posibilita la identificación con el espectador, mientras que el trabajo de Resnais busca interpelar y producir un fuerte impacto sobre el espectador. 
La pregunta que muchos teóricos hicieron: ¿Es posible representar con imágenes el horror del Holocausto? Lazmann también lo intentó hacerlo con su película Shoah que resultó en una película que busca utilizar un tipo de memoria personal a través de la palabra de los testigos. Lanzmann actualiza el acontecimiento y busca que acontezca otra vez en la pantalla, su intención también es provocar la identificación del espectador, como Forgács, pero produce algo de rechazo, pues las imágenes son muy fuertes, así como los relatos, para que haya una identificación. Forgács no busca la espetacularización de los acontecimientos, sino intenta trabajar de manera simple, con pocos comentarios dejando que la memoria del espectador agregue interpretación a la memoria de la familia Bartos que es vista en la pantalla.

En una entrevista con Bill Nicohls, Forgács dice que el "kit" de entrevistas de Shoah es un ejemplo para temer en la industria de las películas hechas sobre el Holocausto, y que estas imágenes ya están archivadas en la memoria del espectador, y por eso, ya no se hace necesario insistir en ellas. En sentido, para él no existen imágenes capaces de mostrar el exterminio, y cualquier escena de los campos de concentración ya no producen el horror, sino que banalizan el horror. Para el director húngaro lo que le interesa es la ruta que nos lleva hasta el acontecimiento histórico partiendo de una posible idea de lo que fue la vida de las víctimas 10.

En Bartos Family el espectador es capturado por sus emociones identificándose con personajes que desconocían las tragedias que les esperaban el siglo XX, es una empatía que también posee una visión critica, principalmente por los comentarios hechos por el director.

Fogács trabaja las imágenes como un arqueólogo, las excava hasta encontrar sentidos que inicialmente no eran vistos. Manipula las imágenes pero no las saca de su contexto inicial, y de esta manera, abre los ojos de los espectadores y funciona como un disparador que los hace reflexionar sobre la historia, la memoria individual y la memoria colectiva. Notas 1. Bernini, E. Found footage. Lo experimental y lo documental. En Cine Encontrado. ¿Qué es y adónde va el found footage? 2. Lins, C. y Blank, T. Ruínas da intimidade: os objetos encontrados por Péter Forgács.

3. Lins, C. y Blank, T. Ruínas da intimidade: os objetos encontrados por Péter Forgács.

4. Weinrichter, A. (2009). Metraje encontrado. La apropiación en el cine documental experimental. p. 96.

5. Bernini, E. Found footage. Lo experimental y lo documental. En Cine Encontrado. ¿Qué es y adónde va el found footage? 6. Bernini, E. Found footage. Lo experimental y lo documental. En Cine Encontrado. ¿Qué es y adónde va el found footage? 7. Bernini, E. Found footage. Lo experimental y lo documental. En Cine Encontrado. ¿Qué es y adónde va el found footage? 8. Weinrichter, A. (2009). Metraje encontrado. La apropiación en el cine documental experimental. p. 97.

9. Weinrichter, A. (2009). Metraje encontrado. La apropiación en el cine documental experimental. p. 99.

10. Rebello, P. y Sampaio, R. Péter Forgács. Aquitetura da memoria.

Bibliografía

Bernini, E. (2010). "Found footage. Lo experimental y lo documental”, en Leandro Listorti y Diego Trerotola (comps.), Cine encontrado. ¿Qué es y adónde va el found footage?. Buenos Aires: bafici. 
Bourriaud, N. (2004). Post producción. Buenos Aires: Adriana Hidalgo. Bonet, E. "Desmontaje documental”, en L. Listorti y D. Trerotola (comps.) Cine encontrado, op. cit.

Farocki, H. (2003). Crítica de la mirada. Buenos Aires: bafici.

Farocki, H. (2013). Desconfiar de las imágenes. Buenos Aires: Caja Negra. Lins, C. y Blank, T. Ruínas da intimidade: os objetos encontrados por Péter Forgács.

Rebello, P. y Sampaio, R. (2012). Péter Forgács. Aquitetura da memoria, CCBB.

Weinrichter, A. (2009). Metraje encontrado. La apropiación en el cine documental y experimental. Navarra: Punto de Vista.

Abstract: The article makes a review of the film Bartos Family (1982) by the hungarian film maker Peter Forgács. The analysis focuses in the use of family archives in the making of the film. Forgás uses ancient archives of an hungarian family between 1920 and 1950 showing the day to day of this group and presenting historic facts preand post the raising of nazism. The director manipulates the images left in their original context: the hungarian society of those times. The meeting between present audiences with those images from the past produces a new look on history. The paper aims to analyze the film editing techniques applied by the director and the impact of found footage in present audiences.

Key words: found footage - family archives - nazism - film editing.

Resumo:

Este artigo propõe uma leitura do filme Bartos Family (1982), do cineasta húngaro Peter Forgács. A análise enfoca-se no uso de materiais de arquivos familiares. Forgács usa arquivos de uma mesma família húngara entre as décadas de 1920 e 1950, e embora descreve o cotidiano deste grupo, apresenta fatos históricos prévios e posteriores à ascensão do nazismo. O diretor manipula as imagens, mas não as tira do contexto original: a sociedade húngara da época. O encontro entre o espectador atual e as imagens do passado produz uma nova maneira de olhar à história. $\mathrm{O}$ estudo analisa as técnicas de montagem utilizadas pelo diretor e como se produz o impacto do found footage no espectador atual.

Palavras chave: found footage - arquivo familiar - nazismo - montagem.

Péter Forgács: imágenes de familia y la memoria del Holocausto fue publicado de la página 55 a página63 en Cuadernos del Centro de Estudios de Diseño y Comunicación № 62 